\title{
Invited perspectives: The volcanoes of Naples: how can the highest volcanic risk in the world be effectively mitigated?
}

\author{
Giuseppe De Natale $^{1,2, \mathrm{O}}$, Claudia Troise ${ }^{1,2}$, and Renato Somma ${ }^{1,3}$ \\ ${ }^{1}$ Istituto Nazionale di Geofisica e Vulcanologia, Via Diocleziano 328, 80124 Naples, Italy \\ ${ }^{2}$ CNR-INO, Via Campi Flegrei 34, 80078 Pozzuoli, Italy \\ ${ }^{3}$ CNR-IRISS, Via Guglielmo Sanfelice, 8, 80134 Naples, Italy \\ Invited contribution by Giuseppe De Natale, recipient of the EGU Sergey Soloviev Medal 2018.
}

Correspondence: Giuseppe De Natale (giuseppe.denatale@ingv.it)

Received: 18 February 2020 - Discussion started: 27 March 2020

Revised: 19 June 2020 - Accepted: 24 June 2020 - Published: 23 July 2020

\begin{abstract}
The Naples (southern Italy) area has the highest volcanic risk in the world due to the coexistence of three highly explosive volcanoes (Vesuvius, Campi Flegrei and Ischia) with extremely dense urbanisation. More than 3 million people live to within 20 kilometres from a possible eruptive vent. Mitigating such an extreme risk is made difficult because volcanic eruption forecasting is currently an empirical procedure with a very uncertain outcome. This paper starts by recalling the state of the art of eruption forecasting, and then describes the main hazards in the Neapolitan area, shortly presenting the activity and present state of its volcanoes. Then, it proceeds to suggest the most effective procedures to mitigate the extreme volcanic and associated risks. The problem is addressed in a highly multidisciplinary way, taking into account the main economic, sociological and urban issues. The proposed mitigation actions are then compared with the existing emergency plans, developed by Italian Civil Protection, by highlighting their numerous, very evident faults. Our study, besides regarding the most complex and extreme situation of volcanic risk in the world, gives guidelines for assessing and managing volcanic risk in any densely urbanised area.
\end{abstract}

\section{Introduction}

Volcanic eruptions, in particular super-eruptions from large calderas, represent one of the highest natural threats to humankind (Newhall and Dzurisin, 1988; Papale and Marzocchi, 2019). However, eruption forecasting is still an empiri- cal, largely uncertain practice. Successful forecasts are very few and sometimes obtained too shortly before the eruption (Consensus Study Report, 2017). Globally, the percentage of timely and correct volcanic alarms is still very low, and failure cases have often resulted in considerable human losses (Winson et al., 2014). Many volcanoes on Earth are located in remote areas that are not densely populated. In remote areas, the only threatening volcanoes are the very explosive ones, in particular large collapse calderas, which are able to produce large-scale catastrophes. However, there are places on Earth in which very explosive volcanic areas are also densely populated; in such cases, the volcanic threat can be very high even in the case of moderate to small eruptions, and the volcanic risk can attain extremely high values. This is exactly the case of the volcanoes located in the Neapolitan area (southern Italy). Neapolitan volcanism is hosted in the larger Campania Plain, a former volcanic field which has given rise to six ignimbritic eruptions since about 300000 to 39000 years BP; the last one (Campanian Ignimbrite, 39000 years BP) is the largest eruption that ever occurred in Europe to our knowledge. The Neapolitan volcanic area has always been (since 4000 years at least) one of the most densely populated volcanic areas in the world (Mastrolorenzo et al., 2006a) and one of the main cradles of Western civilisation (Astarita, 2013). The high attractions of this area, namely mild climate, fertile land, landscapes, hot springs and natural bays and inlets, have in fact always been perceived to be able to overcome the volcanic threat. Since ancient times, Neapolitan volcanoes have been among the most known in the world: Vesuvius, Campi Flegrei and the island of Ischia, all of them very 
explosive volcanoes. In the eighth century $\mathrm{BC}$, the island if Ischia became the first Greek colony on the Italian peninsula, named at the time "Magna Graecia" (Carratelli, 1983). The large metropolitan area of Naples, the largest metropolitan area in southern Italy, contains about 3 million people, all of them living within about $20 \mathrm{~km}$ from a possible eruptive vent. The Neapolitan area is then characterised by the highest volcanic risk in the world, which must somehow be managed and mitigated. In fact, there are emergency plans issued by the national Civil Protection Department in Italy for the two main volcanic areas: Vesuvius and Campi Flegrei. This paper describes the main volcanological issues of the three Neapolitan volcanic areas and the associated risks, and it describes the main problems of the present emergency plans. It then proceeds to define the most important features that a realistic emergency plan aimed at effectively mitigating the extreme volcanic risk of the area, should contain. Mitigation of volcanic risk is addressed here in a highly multidisciplinary framework because the main action needs to start from volcanological considerations but necessarily involves economic, sociologic and urbanistic considerations. The extreme risk of the Neapolitan volcanic area is a paradigm for other volcanic areas of the world. Addressing the best procedures to mitigate volcanic risk here is a very important benchmark for any populated volcanic area in the world.

\section{The state of the art of eruption forecasting and alerts}

Eruption forecasting for timely evacuation is the only way to protect populations exposed to volcanic risk today. In fact, if people can be made safe from earthquakes, provided the edifices are robust enough (which can be a difficult task only where extreme magnitude events occur very close to urbanised areas), there is not presently any possible defence against the most hazardous eruption products (i.e. pyroclastic flows, very fast lava flows or, in some cases, huge pyroclastic falls) other than timely evacuation before the climax of the eruption.

Eruption forecasting is often considered feasible in principle as opposed to earthquake forecasting, today considered impossible. Such statements are equally wrong since eruption forecasting is just easier to imagine because volcanoes are well-identified and localised objects that are easy to monitor, whereas active faults involve very large areas, and specific active patches are not evident. However, eruption forecasting is still a largely empirical matter with a very uncertain outcome (Winson et al., 2014). Although some studies are starting to constrain, with physical considerations and modelling, volcano behaviour forecasting (Kilburn, 2012; Robertson and Kilburn, 2016; Kilburn et al., 2017), this research is still at the forefront and not easily generalisable for practical use. The basic problem of eruption forecasting, which can be dramatic in extreme risk areas (i.e. very densely populated volcanic areas), is schematically shown in
Fig. 1. As can be inferred from the figure, a timely forecast of an eruption occurs when a well-defined alarm is given, followed by an eruption. The alarm can be considered effective if it allows the population to be evacuated before an eruption occurs. If an alarm is issued and not followed by an eruption, it should be regarded as a false alarm. As a consequence, in contrast with an appropriate alarm (implying evacuation), two types of failure should be considered: false alarm and missed alarm. In the most general case, as depicted by Fig. 1, a certain trend of precursory phenomena (which usually involve increase in seismicity, ground uplift and changes in chemical species and/or equilibrium in waters and in gas emissions) increases (more or less monotonically) until the eruption occurs. If the alarm for evacuation is given in the initial phase as these precursors increase, there is a low probability of a missed alarm but a high probability of a false alarm. In contrast, when waiting for the precursory phenomena to become very high, there is a low probability of a false alarm but a high probability of a missed alarm because the eruption could start before having the time to complete evacuation. Thus, given the complete trade-off between false alarm and missed alarm probability, the time of alarm should be given in such a way so as to minimise the "cost", which in the case of a false alarm is the economic and social cost of moving away the population, whereas in the case of a missed alarm it is the loss of human lives likely as a result of the eruption. It is then very clear that, in the case of a large exposed population, the probability of a missed alarm can be unsustainable in terms of human losses as well as of very low values of eruption probability; however, in contrast, a false alarm could have an economic and social cost that is also unsustainable. Failure to correctly manage this problem in the case of a high exposed value can also imply heavy judicial responsibility for decision makers.

The serious complexity of volcanic-risk mitigation when it is extremely high can be further clarified by considering the low degree of confidence of actual forecasting techniques. Given that the catastrophic Mt. St. Helens eruption can be considered to be the starting point of modern awareness of the importance of eruption forecasting, a look at the most renowned eruptions in the literature since 1980 can give initial insight into the problem. A good comprehensive review of the outcomes of eruption forecasting as applied to volcanic eruptions since 1980 has been given in the Consensus Study Report (2017). The outcomes from that report indicate a success rate of much less than $50 \%$ in the forecasting for the most significant eruptions of the last 4 decades. However, even in the case of "successful" forecasts, the time of alarm before the eruption should be taken into account: in fact, the most successful forecast is considered to be the 2000 Hekla eruption, for which a very precise timing of the eruption was predicted but only half an hour before the eruption occurred (Stefánsson, 2011). Obviously, forecasts achieved very shortly before the eruption occurrence are not of any 


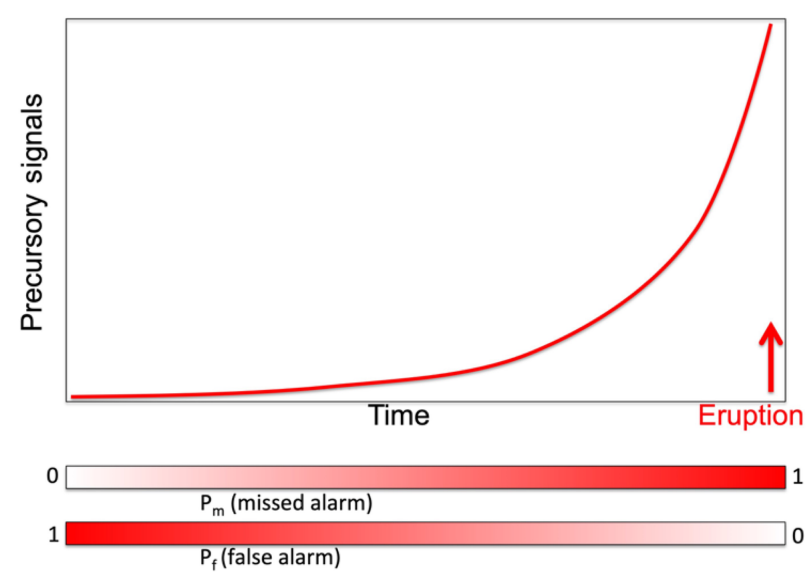

Figure 1. Sketch of an "ideal' evolution in time of precursory signals before an eruption. When declaring an eruption alert shortly after the beginning of precursory signal increase, the probability of a false alarm is very high, but the probability of a missed alarm is low; in contrast, when declaring an alert only when precursory signals are extremely high, the probability of a false alarm is low, but the probability of a missed alarm (in the sense of "too late") is very high because the eruption could start suddenly, before any civil protection measure (normally, evacuation of the most risky areas) can be completed.

practical use for the evacuation of large numbers of people exposed.

A very complete assessment of the state of the art in the practical use of eruption forecasting, evaluated through the timely issue of proper volcanic alerts, has been given by Winson et al. (2014). They analysed 194 eruptions that occurred in the period 1990-2013 from 60 volcanoes, measuring the appropriateness of the issued volcanic alerts. Figure 2 shows the main results of their study: only appropriate volcano alert levels issued by authorities anticipated $19 \%$ of the eruptions. Such a discouraging outcome is only a little bit higher $(30 \%)$ for larger eruptions (VEI > 3); it increases for better-monitored as well as for closed-vent volcanoes but in any case never reaches $50 \%$. In addition, there is an average of $33 \%$ of issued alerts for unrest which did not give rise to eruptions, i.e. "false alarms".

These results clearly show that, presently, the state of the art in eruption forecasting implies that it is much more probable to miss an eruption or to give a false alarm rather than correctly forecast it. In such conditions, the "forecast dilemma" depicted by Fig. 1 becomes very dramatic to solve in extremely risky (i.e. extremely populated) volcanic areas.

Before discussing the implications of such an ambiguous outcome for the extremely populated Neapolitan volcanoes, let us just recall the main elements of the actual emergency plans for these volcanoes, which are based on rather common procedures: (1) defining a "red zone", which should be evacuated before the eruption starts; (2) defining a "traffic light" system, in our case made of four colours (green, yel-
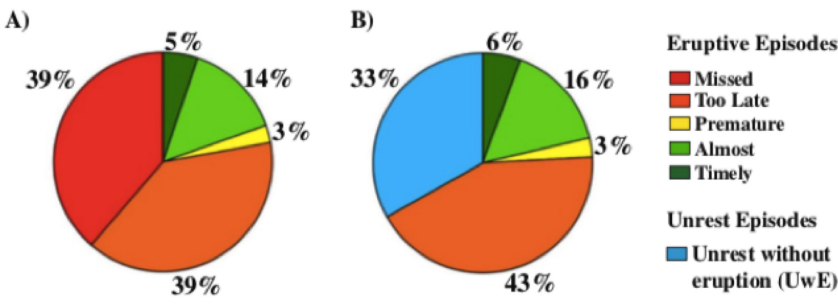

Figure 2. Percentages (in terms of relative frequencies) of successful and unsuccessful volcanic forecasts and warnings (from Winson et al., 2014). (a) Relative frequencies of the eruption forecasts in each category are associated with a colour. Note that successful forecasts (timely and almost timely, in two gradations of green) are only $19 \%$ of the total. (b) Proportion of alerts for unrest without eruption (false alarms) as a percentage of all categories but the first ("missed").

low, orange, red) such that the green level is the "completely quiescent" one, and the hazard level for a possible eruption increases until, with a red alert, the complete evacuation of the red zone must be realised in $72 \mathrm{~h}(3 \mathrm{~d})$.

\section{The Campanian Volcanic Zone and the Neapolitan volcanoes}

The Campanian margin displays the typical features of a continental crust and lithosphere extensional domain: several normal faults, very shallow Moho (Ferrucci et al., 1989), high heat flow values (Della Vedova et al., 2001) and largevolume ignimbrite eruptions (Di Girolamo, 1968; Rolandi et al., 2003, 2019a). All these features indicate that the Campanian Plain forms an elongated sedimentary volcanic plateau, $50 \mathrm{~km}$ long by $20 \mathrm{~km}$ wide, limited to the north, east and south by the Apennine chain. In accordance with these special volcanic and tectonic features, the Campanian Plain (see Fig. 3) has been indicated as the Campanian Volcanic Zone (CVZ; Rolandi et al., 2003; Bellucci et al., 2006a). In the last $600 \mathrm{kyr}$, the CVZ has been affected by uplift and intense volcanism, alternating with periods of subsidence and marine sedimentation (Cinque and Romano, 1990; Scandone et al., 1991). Presently, the Campanian Plain hosts at least three active volcanic areas: Mt. Vesuvius, Campi Flegrei caldera and the island of Ischia. Besides such well-identified volcanic edifices, at least six ignimbrites were emplaced over the $\mathrm{CVZ}$ out of the three mentioned known volcanoes in the last $300 \mathrm{kyr}$ (Rolandi et al., 2003, 2019a). The existence of a unique, large volcanic area involving the whole Campanian Plain, in which the three most known volcanoes are the ones which have erupted in recent times, is supported by seismic tomography studies (Zollo et al., 1996, 2008) which identified a large, thin melt layer spread at least beneath the whole Vesuvius-Campi Flegrei area at a depth ranging between 8 and $10 \mathrm{~km}$. The CVZ is delimited in the northern part by the Roccamonfina volcano, in the southern part by the Somma- 
Vesuvius (SV) volcano complex and Campi Flegrei and offshore by the islands of Ischia and Procida (Rolandi et al., 2019a). The active volcanoes of the Naples district (SommaVesuvius, Campi Flegrei, Ischia and Procida) are described in more detail later. We shortly describe here the Roccamonfina volcano, which is considered to be extinct. It is a large stratovolcano with numerous post-caldera cones within the summit caldera and on the flanks. The eruptive history consists of three main phases. The first stage built the main cone via lava flows and pyroclastics. The second stage is defined by large explosive eruptions, brown leucitic tuff, white trachytic tuff and caldera collapse. The third stage formed the lava domes and scoria cones that exist on the volcanic edifice today (Giannetti and Luhr, 1983). Rouchon et al. (2008) dated summit caldera lava domes back to $170-150 \mathrm{ka}$. Peccerillo (2005) gives an age range of $0.58-0.1 \mathrm{Myr}$ for the whole Roccamonfina activity. Eruptive activity of the Roccamonfina volcano in the last 300000 years is then coeval with five of the six ignimbritic eruptions generated from the CVZ.

The offshore volcanism does not involve only the islands of Ischia and Procida; over $50 \%$ of the Campi Flegrei caldera is below sea level (Somma et al., 2016), and the Gulf of Naples hosts several submerged volcanic centres (Passaro et al., 2015, 2016). The southernmost area then contains the three volcanoes surely active today; about 3 million people live within less than $20 \mathrm{~km}$ from a possible eruptive vent.

\subsection{Mt. Vesuvius}

The Somma-Vesuvius (SV) volcanic complex is the most known volcano of the Neapolitan area and one of the most famous in the world, mainly because of its ancient eruption in AD 79, which was well described by Pliny the Younger (Scandone et al., 2019). SV is also a renowned volcano because it has frequently erupted in the last centuries, thus becoming popular as a natural attraction in Europe and one of the classic stops of the 19th century Italian "grand tour" (Astarita, 2013). The eruptive history of SV, shown in Fig. 4, is characterised by periods of frequent activity (open-conduit activity) alternating with periods of quiescence (closed-conduit periods). The history of SV began 0.3-0.5 million years ago. In the past, closed-conduit periods have lasted up to 1000 years; they are generally interrupted by Plinian and sub-Plinian explosive eruptions, which only differ in the volume of emitted magma and the energy of the eruption. SV is composed of a multistage and older summit caldera (Mt. Somma, $1132 \mathrm{~m}$ a.s.l.) and a nested younger cone (Mt. Vesuvius, $1281 \mathrm{~m}$ a.s.l.; Fig. 3). In the last $25 \mathrm{kyr}$, five Plinian caldera-forming eruptions (Pomici di Codola, $25 \mathrm{ka}$; Pomici di Base, $18 \mathrm{ka}$; Mercato, $9.7 \mathrm{ka}$; Avellino, $4.3 \mathrm{ka}$; and Pompei, AD 79) and at least three major sub-Plinian eruptions (Pomici Verdoline, 17.6 ka; Pollena, AD 472; and AD 1631) occurred (Rolandi et al., 1998). The last cycle of open-conduit activity started in 1631 and lasted until 1944. Since 1944, this area has experienced vast urban development: the population in towns around the volcano tripled, becoming seamlessly connected to the city of Naples. It is important to note that towns around Vesuvius, which were primarily tourism-oriented before the Second World War, are now very busy outskirts of Naples, hosting a resident population. The present activity of this volcano, otherwise quiescent, only consists of a background seismicity seldom overcoming magnitude 2 , with maximum magnitude $M=3.6$ reached by an earthquake on 9 October 1999 , during a period of increased seismicity rate and magnitude that lasted some months (between 1999 and 2000; see De Natale et al., 2004). A convincing explanation for background seismicity at this and similar composite volcanoes was given by De Natale et al. (2000); it is interpreted as resulting from gravitational stress due to the volcano topography load, which is focused along the sharp rigidity contrast between the external rocks made of explosive pyroclastic deposits and the central conduit made of solidified magma. At Vesuvius, however, with the exception of the increased seismicity that occurred in the mentioned period, no other signals of anomalous activity have ever been recorded at this volcano (ground uplift, geochemical anomalies, consistent LP seismicity, seismic tremor etc.).

The volcanic hazard at SV has been thoroughly described in a probabilistic framework: first by Rossano et al. (1998) and then, in a more complete way, by De Natale et al. (2005). The main volcanic hazards are pyroclastic flows and ash and pumice fallout (see also Sacchi et al., 2019, 2020) but also associated hazards like earthquakes, lahars, lava flows and floods, which need to be considered (Sacchi et al., 2009). In particular, large floods caused by the remobilisation, due to heavy rains, of the old, loose pyroclastic deposits on the topographic reliefs around Vesuvius caused nearly total destruction and 160 casualties in May 1998 (Mazzarella et al., 2002).

The Somma-Vesuvius volcano was the first one for which a complex emergency plan had been issued, by Italian Civil Protection, in 1995. The features of this first plan were almost the same as the present ones (Dipartimento Protezione Civile, 2015), although some minor modifications have been made in the last decades. The eruptive scenario, used to define the red zone (shown in Fig. 5), was a sub-Plinian eruption mainly because at the time in which the first plan was released the idea that a shallow magma chamber was almost constantly fed by deeper magma was predominant in the literature (e.g. Santacroce, 1983), and related computations of the volume of magma fed from 1944 were consistent with a sub-Plinian eruption. Later on, such a volcanological hypothesis was heavily questioned, mainly as a consequence of seismic tomography studies which failed to identify such a shallow chamber filled with molten magma (Zollo et al., 1996). In particular, Marzocchi et al. (2004) pointed out that, from probabilistic estimates, after 60-200 years of quiescence a violent Strombolian 


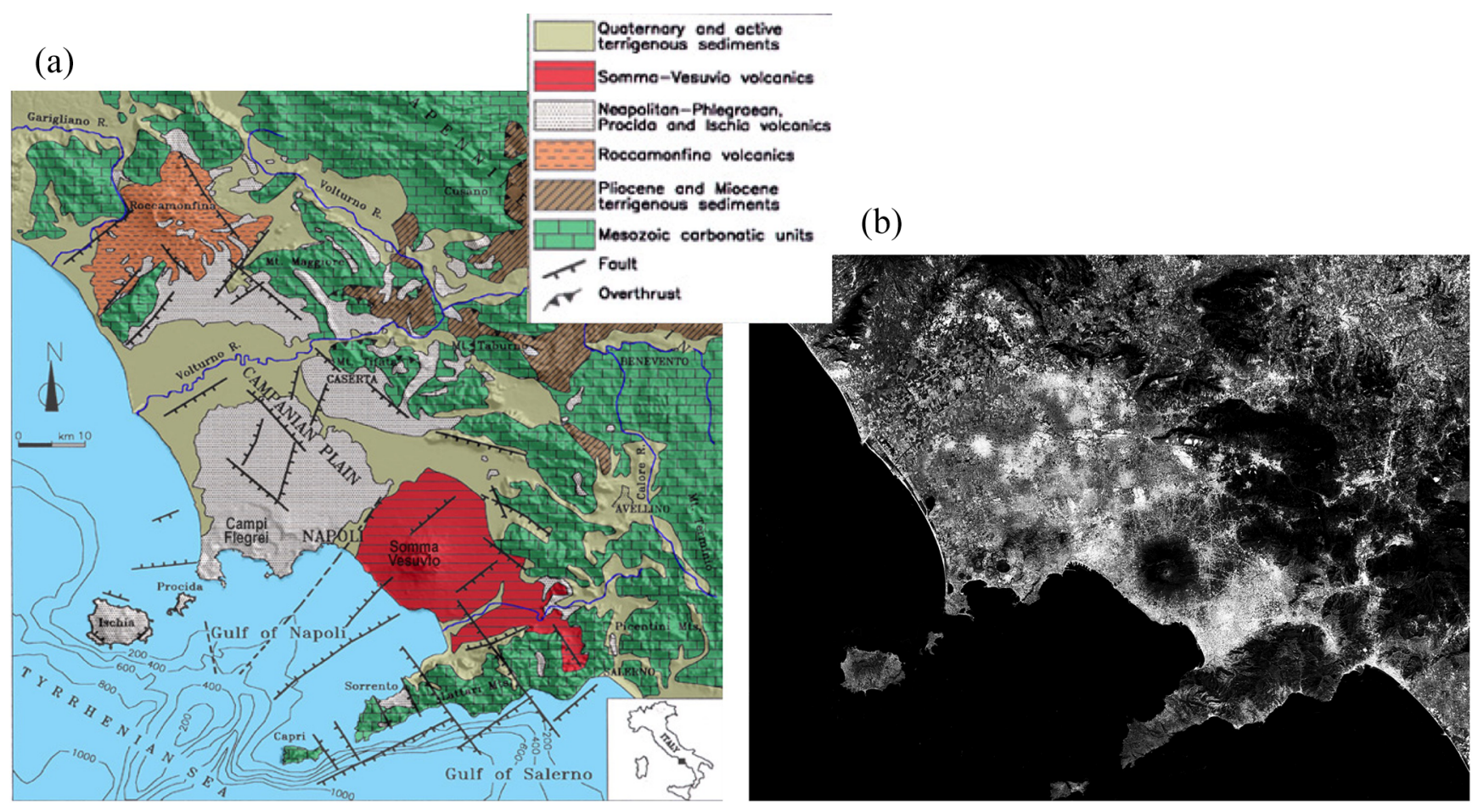

Figure 3. Geological sketch map of the Campanian Plain, with the Neapolitan volcanic area (a; modified from Orsi et al., 1996). Also shown (b; modified from () Google Earth) is a map with the most densely urbanised areas evidenced (more intense white means denser urbanisation). Note that more than 3 million people live in the volcanic area shown, thus making it the most risky in the world.

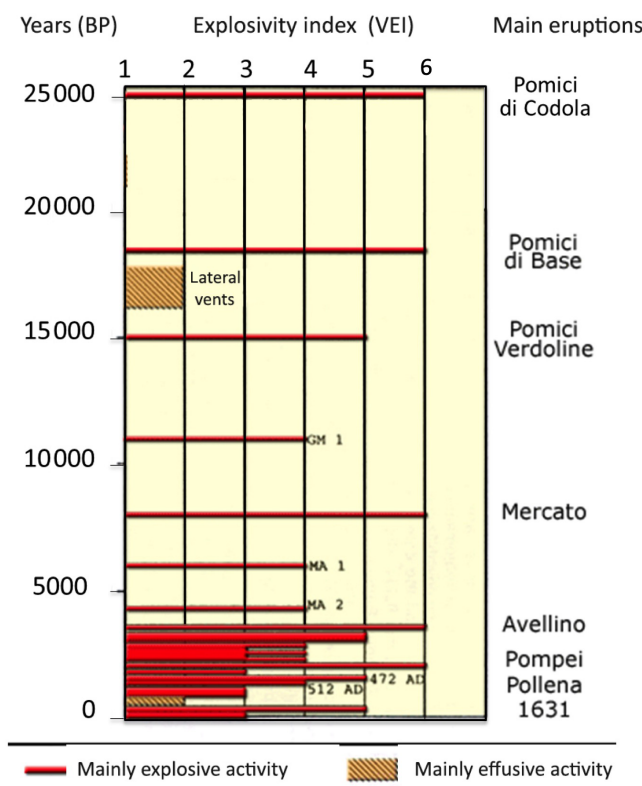

Figure 4. Eruptive history at the Somma-Vesuvius volcano (redrawn after the Osservatorio Vesuviano - INGV website, http:// www.ov.ingv.it/ov/it/vesuvio/storia-eruttiva-del-vesuvio.html, last access: 18 July 2020, and Rolandi, 1998). eruption $(\mathrm{VEI}=3)$ is the most probable event, whereas a sub-Plinian one $(\mathrm{VEI}=4)$ has a much lower probability of occurring, and a Plinian one $(\mathrm{VEI}=5)$ still has a probability of $>1 \%$. However, in the emergency plan the sub-Plinian scenario has been maintained. The updated red zone of Somma-Vesuvius hosts about 700000 residents today, and totally or partially includes 25 municipalities (see the Italian Civil Protection Department website: Vesuvius: http://www.protezionecivile.gov.it/mediacommunication/dossier/detail/-/asset_publisher/default/ content/aggiornamento-del-piano-nazionale-di-emergenzaper-il-vesuvio, last access: 19 July 2020).

\subsection{Campi Flegrei caldera}

Campi Flegrei caldera, located in the southwestern part of the Campanian Volcanic Zone, contains the western district of the city of Naples (see Fig. 3). It is a collapse caldera, formed by the huge eruption of Neapolitan Yellow Tuff, which occurred about 15000 years BP (Rolandi et al., 2003, 2019a; De Natale et al., 2016). Neapolitan Yellow Tuff, a VEI $=6$ event with an erupted volume of about $40 \mathrm{~km}^{3}$, generated pyroclastic flows, which represent the main eruptive products found in the Naples province and had been the main building material in this area for more than 2000 years before the concrete became diffused. One of its facies, named "Pozzolana" (from the name of the town, Pozzuoli, located at the caldera 


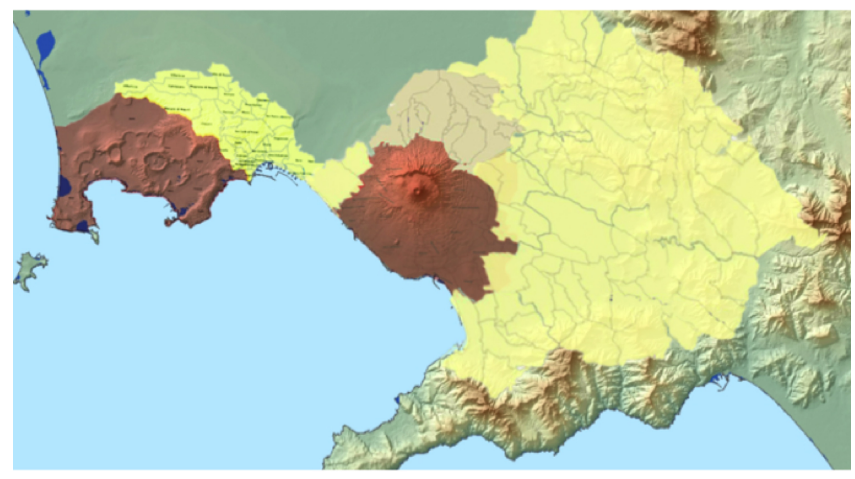

Figure 5. Red and yellow zones for Campi Flegrei and Vesuvius. Red zones are the areas with maximum pyroclastic flow hazard, which have to be completely evacuated within $72 \mathrm{~h}$ from the declaration of "red alert". Yellow zones are the areas with maximum hazard for accumulation of pyroclastic falls on flat roofs (see Vesuvius: http://www.protezionecivile.gov.it/documents/20182/0/mappa_ zona_gialla.pdf/03fbcf72-60bc-4b00-b9a7-5b39f88f0e99, last access: 19 July 2020; Campi Flegrei: http://www.protezionecivile. gov.it/documents/20182/0/Allegato_1_delibera_zona_gialla_ flegrei.pdf/4220a109-34be-46ae-946d-53469e6b8891, last access: 19 July 2020).

centre), was the main element composing the famous "Roman cement", which allowed ancient buildings of the Roman age to be so resistant and long-lived (Vanorio and Kanitpanyacharoen, 2015). Campi Flegrei caldera has long been thought to be first formed by the largest European eruption ever known, namely the Campanian Ignimbrite, a VEI $=7$ event whose erupted volume estimates range between 150 and $300 \mathrm{~km}^{3}$ (Rosi and Sbrana, 1987; Orsi et al., 1996). However, Rolandi et al. (2019b) recently demonstrated that Campanian Ignimbrite's main products (grey tuff) were erupted from the Campanian Plain, north of Campi Flegrei, and did not cause any caldera collapse. Campi Flegrei caldera eruptive activity has been dominated by phreatomagmatic eruptions, whose explosivity is due to the contact of rising magma with the large geothermal system located beneath the caldera, down to about 2.5-3.0 km (Rosi and Sbrana, 1987; Piochi et al., 2014). The collapsed area, as recognised by geophysical data (Cassano and La Torre, 1987; Capuano and Achauer, 2003), has a radius of about $3 \mathrm{~km}$, with the centre approximately located at the Pozzuoli town harbour; more than $50 \%$ of the caldera is below sea level (Somma et al., 2016; Steinman et al., 2018; Sacchi et al., 2019). All the eruptions younger than 10000 years are located within such an area, occurring more frequently from its borders, marked by buried caldera ring faults (De Natale and Pingue, 1993; De Natale et al., 1997). The eruptive history of Campi Flegrei is sketched in Fig. 6. The only eruption in historical times that occurred in 1538, and this is the reason why this volcanic area is by far less renowned than Vesuvius. However, this area is also characterised by unrest episodes with large uplift and subsidence of the ground level. In the last 2000 years, subsidence has been generally dominant at an almost constant rate of between 1.5 and $2.0 \mathrm{~cm} \mathrm{yr}^{-1}$ except during about 1 century preceding the 1538 eruption, when fast uplift occurred at an average rate of about 1 order of magnitude larger than the secular subsidence (see Fig. 7). Another episode of fast uplift, but without a subsequent eruption, has been inferred by Morhange et al. (2006) between the seventh and the eighth centuries. Starting in the 1950s, the ground movements in the area again reversed to uplift, which between 1950 and 1984 totalled about $4.5 \mathrm{~m}$, with peak rates of about $1 \mathrm{~m} \mathrm{yr}^{-1}$ between 1983 and 1984. After about 20 years of relatively fast subsidence following the 1984 peak of vertical ground displacement, uplift started again around 2005 (Fig. 7) at rates comparable to those of subsidence (on average $9 \mathrm{~cm} \mathrm{yr}^{-1}$ ) but much lower than previous uplifts (Moretti et al., 2018; Troise et al., 2019). Both the post-1984 subsidence and the subsequent and still ongoing uplift phase showed minor, short-lived peaks of uplift followed by a fast recovery of the whole uplift (the so-called "mini-uplift" episodes; see Gaeta et al., 2003; Troise et al., 2007; Iuliano et al., 2015). The intermittent uplift phases, which started in 1950 and are still ongoing, show a cumulative uplift in about 70 years consistent with an average rate of $0.075 \mathrm{~m} \mathrm{yr}^{-1}$. The average uplift rate computed from the total uplift observed since about 1.5 centuries before the 1538 eruption, although in the very rough approximation of secular inferences, is about $0.1 \mathrm{~m} \mathrm{yr}^{-1}$, which is the same order of magnitude and not clearly distinguishable considering the large uncertainties. The 1950-2019 unrest, with intermittent ground movements and seismicity, gives a very precise idea about the large uncertainty involved in identifying true eruption precursors in this area (Moretti et al., 2013, 2020; Troise et al., 2019). In 1970, during the first, fast uplift episode clearly identified, the urban area of Pozzuoli closest to the harbour, namely the "Rione Terra", was completely evacuated and never inhabited again. In 1984, the whole town of Pozzuoli was evacuated (in the newly built town of Monteruscello) and spontaneously reoccupied some months after, when seismicity stopped and the ground started to subside (Barberi and Carapezza, 1996). Today, after about 15 years of uplift at an average rate of about $0.08-0.09 \mathrm{~m} \mathrm{yr}^{-1}$ and after about 60 years of intermittent unrest, it is not clear yet whether Campi Flegrei caldera is going towards an eruption (Chiodini et al., 2016; Kilburn et al., 2017; Forni et al., 2018; Troise et al., 2019). Campi Flegrei then represents a typical example of an area where short-term forecasting is made particularly difficult due to the problem of distinguishing between hydrothermal and magmatic effects during unrest (Moretti et al., 2017, 2018, 2020). Troise et al. (2019) recently demonstrated that the 1982-1984 unrest was accompanied by a shallow magma intrusion (with a volume of about $0.06 \mathrm{~km}^{3}$ ), whereas the present unrest (started in 2005) cannot be ascribed to shallow magma migration. It is due to the rising of magmatic gases and consequent heating of 


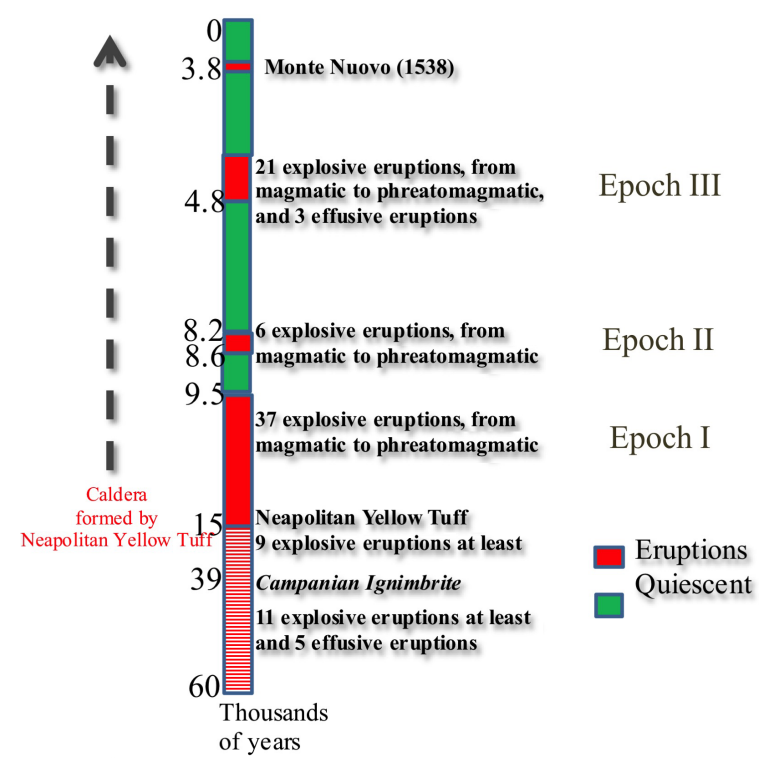

Figure 6. Eruptive history of Campi Flegrei caldera. Note that, according to recent results (De Natale et al., 2016; Rolandi et al., 2019b) the Campi Flegrei caldera was formed by Neapolitan Yellow Tuff (15 kyr BP), and only hosted secondary events of the Campanian Ignimbrite (39 kyr BP) whose main vents opened north of Campi Flegrei area (in the Campanian Plain).

the shallow aquifers. Whatever the physical explanation of the ongoing unrest, however, the area has been in the alert level "yellow" ("attention" level) since December 2012. Recent unrest events, however, have naturally required a wellorganised response at least in the average long term because we cannot actually predict the possible future evolution of the state of the volcano.

It is worth noting that the emergency plan for Campi Flegrei, which is on the way to being completed, did not exist yet at the end of 2012, and not even the red zone was defined (it was officially released in 2015; see the Civil Protection Department website). This probably occurred because, unlike the first edition of the Vesuvius emergency plan of 1995, there was no idea of a given eruptive scenario for this area; not even the eruptive vent could be defined because it could be anywhere in the caldera area. In fact, Rossano et al. (2004) first suggested using a probabilistic scenario made up of any possible kind of eruption from any possible vent spanning the caldera area; the probability of each eruption type was inferred from its frequency in the last 10000 years. Rossano et al. (2004), using a rigorous Bayesian approach and a simplified modelling technique for pyroclastic flows on the actual topography, first obtained a probability hazard map which clearly indicated an area very similar to the presently defined red zone as the most probable zones experiencing pyroclastic flows. More accurate results, using the same methodology, were further obtained by Mastrolorenzo et al. (2006b). However, their hazard maps were never considered by Civil Protection authorities at the time, and only 11 years after did they make the red zone official, based on a paper by Neri et al. (2015), which used a very similar probabilistic approach (although with a much more approximated and less rigorous pyroclastic flow modelling technique). The only difference between the two methods (besides the oversimplification of pyroclastic flow modelling) is that Neri et al. (2015) assumed a non-uniform probability for the vent opening based on the assumptions and results of Bevilacqua et al. (2015). Regarding the definition of the red zone, the final results are very similar to the results obtained by Rossano et al. (2004) and Mastrolorenzo et al. (2006b). The red zone of Campi Flegrei hosts about 600000 residents today, and totally or partially includes six towns and several suburbs of Naples (see the Italian Civil Protection Department website: http://www.protezionecivile. gov.it/attivita-rischi/rischio-vulcanico/vulcani-italia/flegrei/ piano-nazionale-di-protezione-civile, last access: 19 July 2020).

\subsection{The island of Ischia}

The island of Ischia, located south-west of Campi Flegrei, is another volcanic field characterised by both effusive and explosive eruptions (see Passaro et al., 2015). Eruptions here, in fact, range from lava flows to phreatomagmatic ones, thus being halfway between the Vesuvius and Campi Flegrei eruption styles. The Ischia volcanism developed between about 130-150 ka (Vezzoli, 1988) and AD 1302 (de Vita et al., 2006, 2010). Figure 8 shows the eruptive history of the island of Ischia. The volcanism on the island is strictly linked to the resurgence phenomena of Mt. Epomeo, a horst which is thought to move up and down (with dominant uplift in the past due to its prominently high topography). Resurgence has been ascribed to repeated injections of magma at depths of $2-3 \mathrm{~km}$, where a laccolite magma chamber is hypothesised (Orsi et al., 1991; Cubellis and Luongo, 1998; Tibaldi and Vezzoli, 1998; Acocella and Funiciello, 1999; Molin et al., 2003; Carlino et al., 2006; Paoletti et al., 2009; Sbrana et al., 2009). The last eruption occurred in 1302, so common people often do not recognise Ischia as a volcano. The movements of the Epomeo horst also cause slip on the bordering faults, which decouple it from the rest of the island. For this reason, Ischia has been struck in the past by several catastrophic earthquakes that, although not so high in magnitude, are very shallow and very destructive within short distances (see Table 1 in De Natale et al., 2019). The most destructive earthquake to our knowledge was the 23 July 1883 event, which completely destroyed the town of Casamicciola and parts of neighbouring towns, killing 2313 people (De Natale et al., 2019). This catastrophic event was preceded by a slightly smaller event 2 years before, still killing 126 people; these two larger events were the final ones of a sequence of six large earthquakes that started in 1828 (which killed 56 people; see De Natale et al., 2019). After 134 years of 


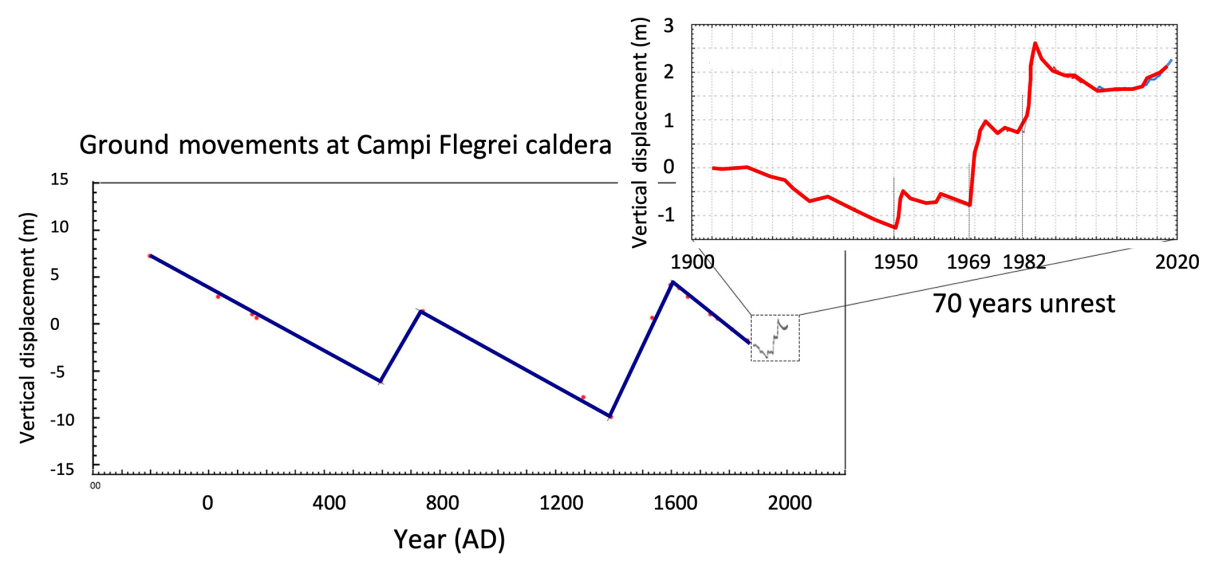

Figure 7. Ground movements at the Campi Flegrei caldera centre (Port of Pozzuoli). The larger figure shows secular displacements, inferred from the traces of marine ingression on the archaeological remains of Serapeo (redrawn after Bellucci et al., 2006b, and Troise et al., 2019). The enlarged figure shows the vertical displacements observed between 1900 and the present; data here are from precision levellings until 2000 and then from continuous GPS measurement.

negligible microseismicity, a new, larger earthquake occurred on 21 August 2017 (De Natale et al., 2019), killing two people and causing severe damages in a specific area between Casamicciola and Lacco Ameno (the same one experiencing the most severe damages and/or destruction from the major earthquakes of the 19th century). De Natale et al. (2019) also warned that the 2017 earthquake could represent the beginning of a new major earthquake sequence just like the 19th century one, further suggesting detailed and urgent mitigation measures. The occurrence of the 2017 earthquake also raises the question of whether such major seismicity could be linked to magmatic pressure increase. Looking at the past activity, there does not appear to be any clear correlation among major earthquakes and eruptions, but we do not know much about the eruption precursors since the last eruption, dating back to 1302. In fact, there is not even agreement about the dip of the fault plane and earthquake mechanism (Nappi et al., 2018; De Novellis et al., 2018; Calderoni et al., 2019), which is critical to understanding whether the event corresponds to an uplift pulse of the Epomeo horst (which could reflect a pulse of increased magma pressure) or to cumulated subsidence (in the last decades the Epomeo horst has been subsiding at an average rate on the order of $0.1-0.5 \mathrm{~cm} \mathrm{yr}^{-1}$ ).

Despite the high hazard posed by seismic and volcanic activity on the island, which hosts about 70000 residents in only $46 \mathrm{~km}^{2}$, the risk here has been generally understated, and in fact neither an emergency plan for volcanic eruptions nor an appropriate plan to secure urban areas from seismic risk has been undertaken until now (besides specific suggestions and warnings given by De Natale et al., 2019). The island of Ischia also represents the absolute need for planning an eventual evacuation by sea routes, which have until now been completely neglected in the Vesuvius and Campi Flegrei emergency plans.

\section{The emergency plans: short history and description}

Emergency plans for the Neapolitan volcanic areas date back to 1995 , the year in which the first plan, related to Mt. Vesuvius, was released. The scenario used for the next eruption of this volcano was a sub-Plinian one, i.e. taking as reference the large eruption of 1631, which opened, after several centuries, the eruptive period that ended with the last eruption of 1944. At the time when the plan was elaborated, the prevailing scientific opinion was that the main magma chambers were refilled at a constant rate (Santacroce, 1983); based on such assumptions, the computed magma volume after 50 years gave almost the same value as the erupted volume computed for 1631. Based on such a scenario, the red zone was defined as the one which could be hit by pyroclastic flows during a sub-Plinian eruption (similar to the 1631 one). In more recent times, such a model of constant magma chamber replenishment has been abandoned, although the red zone has remained almost the same. Besides the red zone as the most prone to pyroclastic flow hazard, a yellow zone has been defined as the most prone to large thickness of pyroclastic falls (i.e. ash and pumice). Since the first emergency plan of 1995, some basic assumptions have been established and used for subsequent plans, for instance the alert levels. In fact, there are four levels of alert: green (basic level, no anomalies), yellow (first alert, some anomalies), orange (pre-alarm, several anomalies) and red (alarm, evacuation). The red zone of Mt. Vesuvius at the time contained about 800000 people. After it was released, the definition of the red zone for Vesuvius gave rise to strong (and sometime harsh) scientific and political discussions; however, in the literature, the scientific debate about the emergency plan and in general about the volcanic hazard and risk in this area can be synthesised by few papers (e.g. Scandone et al., 1993; Rolandi, 2010; Papale, 2017). The main objections to that plan ques- 


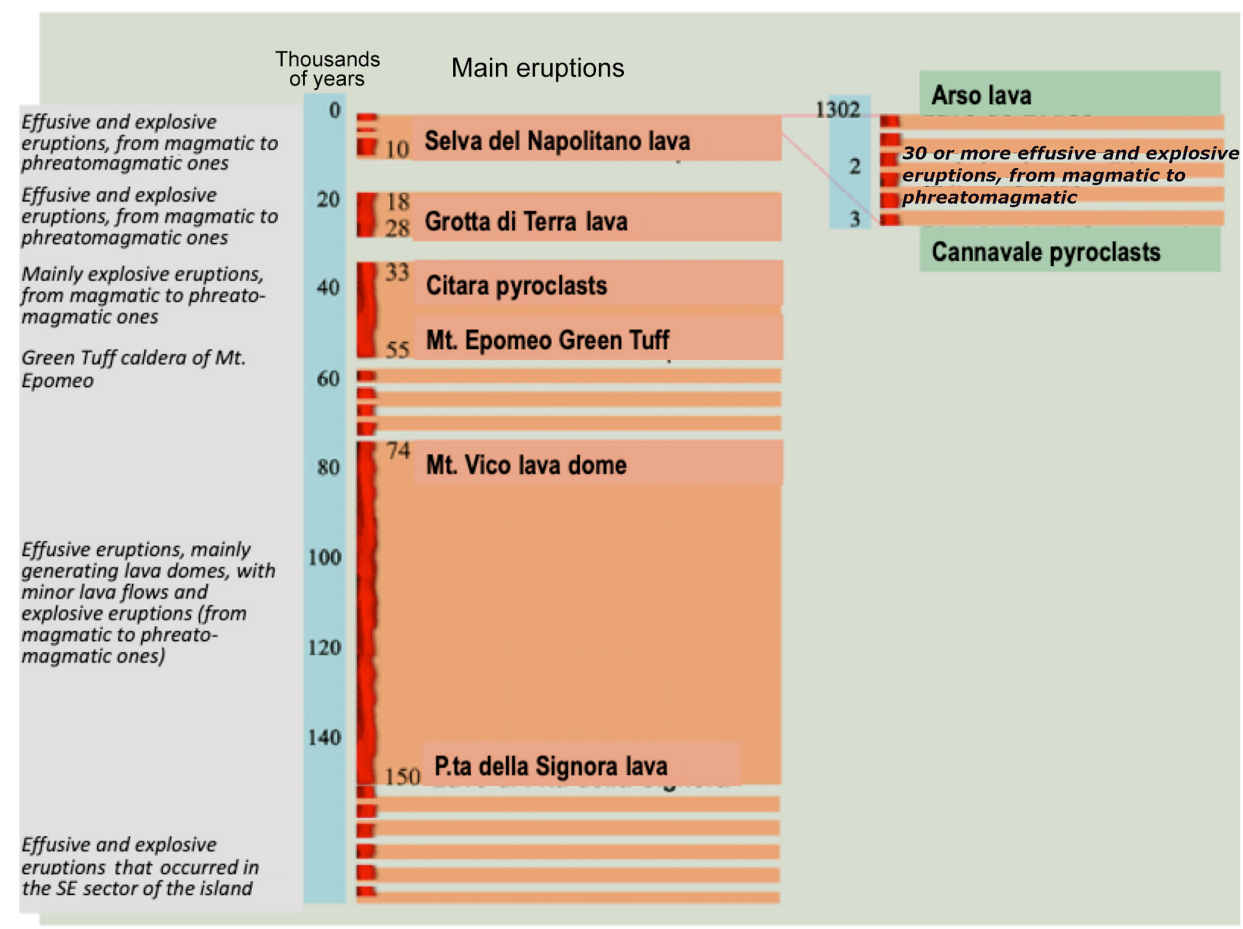

Figure 8. Eruptive history of the island of Ischia.

tioned the choice of the scenario and the possibility to really evacuate 800000 people in $3 \mathrm{~d}$, as set forth in the plan. Most of the criticism addressed the choice of a single scenario, which was based on a sub-Plinian eruption and indicated by a constant-magma-feeding model that had not been supported in the literature since the year 2000. Alternative scenarios, based on probabilistic (Bayesian) hazard estimation from the whole spectrum of possible eruptions, were first proposed by Rossano et al. (1998) but never adopted. The present red zone is shown in Fig. 5 and contains about 700000 people. Since 2015, the red zone for Campi Flegrei eruptions has also been released (Fig. 5). Unlike the Mt. Vesuvius one, the red zone for Campi Flegrei was not designed on the basis of a specific scenario but by taking into account, with a probabilistic approach, the whole spectrum of possible eruptions (Neri et al., 2015), just like Rossano et al. (1998) had first suggested for Vesuvius and then for Campi Flegrei (Rossano et al., 2004). The Rossano et al. (2004) probabilistic approach for the Campi Flegrei pyroclastic-flow hazard map, developed 11 years before the study was adopted to define the red zone (Neri et al., 2015), gave very similar results for the area with maximum probability of being hit by pyroclastic flows and then for the red zone.

What is also relevant for the subsequent considerations is that, regarding the evacuation plan in the case of a red alarm, the two existing emergency plans (for Vesuvius and Campi Flegrei) rely only on the use of land transportation and do not consider the use of ships. This choice, probably driven by the concern for possible tsunamis accompanying erup- tions (extremely rare in such areas anyway and surely not expected before the eruption), cannot be equally applied to an emergency plan for the island of Ischia, which is the only remaining volcanic area where there is not yet any plan.

Natural hazards on the island of Ischia have always been surprisingly underestimated. Despite the catastrophic earthquakes that occurred in the past in the Casamicciola area, including the devastating one of 1883 , causing about 2300 casualties (De Natale et al., 2019), there were no seismic monitoring stations on the island until 1993, when the first permanent monitoring network was installed at three sites then improved with the fourth site in 2015 (De Natale et al., 2019). The recent earthquake that occurred in August 2017, as already discussed, poses a new heavy concern regarding the vulnerability of urban areas (De Natale et al., 2019) and because, at present, the relationship of such seismicity with eventual volcanic processes is not clear at all (Calderoni et al., 2019; Nappi et al., 2018; De Novellis et al., 2018).

Coming back to describe more details of the emergency plans, it is important to note that the first three steps of the alert (green, yellow and orange) are decided by the national Civil Protection Department, normally upon advice from the National Commission for Prevention and Management of Major Risks, whereas the last step, from orange to red (implying complete evacuation of the red zone in $72 \mathrm{~h}$ ), is only decided by the Italian Premier (Dipartimento Protezione Civile, 2015). Regarding the evacuation plan, which starts once the red alert is declared, evacuated people are meant to be distributed throughout all Italian regions according to cor- 
respondence between each municipality and a given Italian region. There is however no other detail in the plan, programming, for instance, exactly where (in which houses, hotels etc.) people will be relocated in each Region.

\section{Evacuation plans: strength and weakness}

We do not aim to discuss in detail the emergency plans in their intermediate steps. We only focus on what should occur after the declaration of the red alert, which implies the rapid (within $72 \mathrm{~h}$ ), complete evacuation of the red zone. As already mentioned, the red zones of Campi Flegrei and Vesuvius presently contain, respectively, about 600000 and about 700000 people. The evacuation plans, in the present formulation, state that they must be evacuated by roads on land. Most residents in the red zones (and also out of them) are sceptical about the real possibility of successfully evacuating such a high number of people within $3 \mathrm{~d}$ (Solana e al. 2008; Carlino et al., 2008). They believe it would not be possible because of both the likely massive panic that would spread across and the major traffic which characterises the few main roads for evacuation, even on normal days. In the turmoil that would likely accompany a massive evacuation, it is easy to imagine those roads completely jammed. These are, however, just feelings of the people, and we will assume here that the evacuation can be successfully organised. There are two former successful examples of evacuation in the Neapoli$\tan$ area, both of them in the Campi Flegrei area. The first evacuation occurred in 1970, at the beginning of the first recent (recognised) large Campi Flegrei unrest during the period 1969-1972. About 3000 people were forcedly evacuated in just 1 day from the Rione Terra, a district of Pozzuoli just behind the Port of Pozzuoli, which was at the time (and also in the following unrest episodes) the area of maximum uplift. After that episode, in 1984, when the subsequent unrest had rapidly progressed, and continuous earthquakes caused extreme concern, the whole town of Pozzuoli, about 40000 people, was evacuated and transferred to a new town: Monteruscello, located about $3 \mathrm{~km}$ north-west and built in few months to host the Pozzuoli citizens (Barberi and Carapezza, 1996). The evacuation of Pozzuoli was, in the opinion of several experts, probably the most successful operation of Civil Protection in Italy. However, it involved more than an order of magnitude fewer people with respect to the present red zone of Campi Flegrei (or, equivalently, of Vesuvius). In addition, the main productive activities (factories) in the Pozzuoli area were not stopped, and evacuated people could go to work anyway in the red zone of that time. Finally, while the Rione Terra was never allowed to be populated again, the complete evacuation of Pozzuoli lasted about 1 year or less, and after that period the town was fully populated again because people almost spontaneously came back. The red zones defined in the present emergency plans are chosen in order to take into account the largest eruptions hav- ing non-negligible probability, so involving very large numbers of people; some volcanologists ask for even higher precaution (e.g. Mastrolorenzo et al., 2017). However, defining very large red zones to be evacuated before an impending eruption could seem more cautious, but it also makes the evacuation decision a much heavier responsibility to assume and dramatically costly in the case of a false alarm. The success of the first two evacuations was undoubtedly due to the limited area and limited number of people involved. Each of them was in effect a single step following the concept of a progressive evacuation in which areas progressively larger could be involved following the eventual increase in anomalous phenomena and/or the start of phreatic activity or magmatic eruption. The concept of progressive evacuation has actually also been implicit in the few successful evacuations before eruptions, which proceeded in steps, enlarging the evacuated areas in response to the increase in eruptive activity (Tayang et al., 1996).

Another choice - which could be surely debated - about the effectiveness of the present evacuation plan is the lack of evacuation by sea with large ships which could rapidly move a lot of people without any traffic problem. This choice is probably due to the fact that the ports in the towns of Campi Flegrei and Vesuvius (except for the Port of Naples) are not suited to host large ships; another obstacle is probably thought to be the possibility that tsunamis may accompany the eruptions. Evacuation by sea is the only type of evacuation that can work as an evacuation plan for the island of Ischia; it is compelling and sooner or later must be done. Moreover, looking at historical eruptions of Neapolitan volcanoes, it turns out there is no evidence for any tsunamis associated with their eruptions.

We proceed now to make clearly evident the main problems of the present-day emergency plans. As already said, we do not discuss the steps from green to orange nor do we want to assess the details of the first evacuation phase, i.e. the way to move 600 000-700 000 people out of the red zone. Regarding the present choice to move people exclusively on land, we just noted that evacuation by sea, using large cruise ships, would be much more rapid and effective by avoiding the multiple problems linked to traffic and to the lack of appropriate roads.

Instead, we want to discuss two problems here which are also in some way interrelated: the extremely high number of people to evacuate in the case of an impending eruption and the lack of plans today to reallocate such a high number of evacuated people while taking into account realistic times people will have to spend out of their homes in the red zone.

Regarding the first problem, namely the high number of people to evacuate, it is clear that the decision makers have to take on a very big responsibility to declare the red alert, which will cause dramatic social problems and economic damages. The economic loss each year the evacuation lasts can be reasonably estimated by considering that 600000 people make up almost $1 \%$ of the total Italian population. Sud- 
denly stopping the economy produced by 600000 people would represent a loss of $1 \%$ of the Italian GDP. Since the annual Italian GDP is around EUR 2000 billion, $1 \%$ is about EUR 20 billion. The cost of assistance to the evacuated people (travel, hosting, subsistence, services etc.), the minimum estimate of which is EUR 15000-20000 per year per person, gives another EUR 10-20 billion per year that must be added to this already high cost. A total cost in the range of EUR 30-40 billion per year (for Campi Flegrei; for Vesuvius it would be about $20 \%$ larger) represents the amount of one of the largest annual financial packages of the Italian government; it is therefore likely unsustainable, even for just 1 to 2 years. But the real problem, which is also fundamental to evaluating the real amount of social disease and total economical loss, is the second one: how much time will such a large number of people spend out of the original towns? To answer this question, we can consider two possible events:

1. The eruption occurs in short times after the alert.

2. The eruption does not occur in short times.

In the first case, it is clear that a considerable part of the evacuated area will be destroyed or at least seriously affected so that several years, probably decades, will be needed to restore conditions to make the area liveable again. In any case, the occurrence of an eruption would likely indicate a new state of the volcano dynamics, making its subsequent activity even more unpredictable. A clear example of such a long-lasting eruptive phase for a volcano which was quiescent for 400 years is the case of Soufrière Hills in Montserrat, which erupted for the first time in 1995 and were evacuated since then; they are still in a state of alarm because of consecutive eruptions (Smithsonian Institution website, https://volcano.si.edu/volcano.cfm?vn=360050, last access: 19 July 2020, and references therein).

Regarding Neapolitan volcanoes, volcanologists normally assume that, after a long non-eruptive period, a new eruption of Mt. Vesuvius will open a new cycle of eruptive activity, which can become much more frequent like it was during the period between the 17th and 20th centuries (Santacroce, 1983). For Campi Flegrei and Ischia, which have been dormant for several centuries, the occurrence of an eruption today would make the future evolution of volcanic activity much more unpredictable. All these considerations make very evident that, on the basis of objective considerations, realistic times to repopulate the red zone would be extremely long or indefinite in Event 1.

What would happen if, on the contrary, the eruption would not occur in short times after the evacuation (Event 2)? In this case, we have to consider that, if the precursory signals were so strong and evident so as to convince decision makers to evacuate 600000-700 000 people, causing a real "disaster" in an economical and social sense, they could certainly not decide to put people back in the same high-risk situation considering that times of preparation of an eruption are mostly unknown but can certainly be very long in some cases. Also in this case, a typical example of what could happen is given by the unrest episodes at Campi Flegrei. We know that intense uplift episodes started in as early as 1950, although apparently that unrest was not noted. However, after the unrest of 1969-1972, people thought the danger was over even if the Rione Terra, the urban area very close to the port, which was evacuated at that time, was never repopulated again. After about 10 years, a new unrest episode started with even higher rates of uplift and much more intense seismicity (De Natale et al., 1991). Once again, at the end of 1985, people thought the danger was over, and Pozzuoli was populated again after the evacuation. However, after about 20 years, a new unrest episode started that is still ongoing today and again poses a large concern among volcanologists, authorities and the population. In practice, the alert at Campi Flegrei lasted 70 years until now and is still ongoing. The first evacuated zone, Rione Terra (3000 people evacuated), has not been repopulated; Pozzuoli was, but it must be noted that only 40000 people were evacuated, that the main economic activities were not stopped and that Monteruscello (the new town hosting evacuated people) was very close to Pozzuoli and inside the municipality of Pozzuoli. In the case of 600000-700 000 people scattered all throughout Italy (as the present evacuation plan prescribes), it would be impossible today to consider the possibility of them coming back to their homes in similar conditions.

Finally, let us make a comparison with another catastrophic emergency that has recently occurred: COVID-19, which has caused economic damages for Italy on the order of some hundreds of millions of euros in a lockdown that lasted 2-3 months. With an unplanned, sudden massive evacuation of Campi Flegrei or Vesuvius, as presently planned, the same amount of economic loss would be totalled in the first few years. However, in this case, such loss would be accompanied by additional catastrophic social unrest due to the uprooting and provisional reallocation of almost a million people.

\section{Elements for a reliable evacuation plan and emergency management}

The nature and size of volcanic hazard in the Neapolitan areas as well as the experience of previous evacuations inside the Campi Flegrei area give important suggestions on how to develop an emergency plan that really works. The previous experiences of evacuation inside the Campi Flegrei area were successful (although no eruption occurred) but limited to 3000-40 000 people. Increasing the number of evacuated people by 1 to 2 orders of magnitude, although it could seem to be more conservative with respect to the possible occurrence of larger eruptions, introduces additional, very huge problems. They are related, as we have explained in the previous paragraph, to the extreme responsibility taken by decision makers in terms of economic and social costs as com- 
pared to the high uncertainty about the evolution of volcanic phenomena. These problems necessarily translate into very long times of permanence of evacuated people out of the red zone in the case of an evacuation. Such times can be estimated, in the most optimistic way, to be on the order of many years or decades. This means that the evacuation plan cannot simply ensure that all people go away safely from the red zone: it must provide a sort of "second life" for the evacuated people, who must live in the new place for decades, perhaps forever. Obviously in this case it is not realistic to assume (as the present plan implicitly does) that several hundred thousand people can live for decades as refugees in temporary government-assisted accommodation like hotels. Making some simple (and optimistic) calculations, besides the unbearable social unease, the economic costs of such a condition would be on the order of EUR 30-40 billion per year. The economic and social costs of an evacuation from one of the two main volcanic areas, operated as imagined until now, thus clearly demonstrate that this is not only a problem for Italy but surely on a European scale.

It should now be clear that the problem of volcanic hazard in the Neapolitan area cannot be addressed in the way it has been until now. In view of a rational approach to this incredibly hard problem, some basic conditions should be reached well before the start of a volcanic crisis possibly leading to an eruption. The most basic conditions are as follows:

1. The number of residents in the red zones must be decreased.

2. The urban areas in the red zones must be made less densely populated and chaotic, with large roads, escape routes and edifices resistant to seismicity that accompanies volcanic unrest.

3. The evacuation of the population must be completely organised well before the crisis; all people should be given a new home, a new working perspective and all the services for living there for many years or decades, likely forever (schools, hospitals, medical care, leisure activities etc.).

The first two points are fundamental in order to make a massive evacuation in the case of a red alert really feasible and to protect the population from the most common phenomena (mainly earthquakes) occurring during unrest and preeruptive phases. In contrast, the third point is compelling in order to prevent a possible evacuation from resulting in a social and economic disaster. However, careful prior organisation of a future evacuation for all the population (point 3 ) may also help to address point 1 - and consequently point $2-$ of the problem. In fact, prior organisation of the "second life" of people in the case of an evacuation may convince several people, if incentivised in some way, to abandon the red zone well in advance of any significant official alert. A significant decrease in residents in the red zone (point 1) will make it easier to reorganise and replanning the urban areas, making them more resistant and resilient (point 2). Associated with these measures, another important improvement of the emergency plans would be to introduce the concept of "progressive evacuation". At present, only massive, total evacuation of the whole red zone is considered in the emergency procedures. As we already discussed, deciding to move several hundred thousand people is a very huge responsibility for decision makers in particular because, even in the presence of strong anomalies which can be considered to be pre-eruptive signals, the probability of a false alarm is extremely high, probably higher - even very close to the eruption time - than the probability of eruption. The experience of the past, and in particular the two successful but limited evacuations in the Campi Flegrei area (1970 and 1984: 3000 and 40000 people, respectively), suggests operation of a progressive evacuation starting in a limited area where precursory signals (and/or prior data) indicate the highest probability of eruption and/or of phreatic explosions and then proceeding to progressively larger areas if the pre-eruptive signals increase (or first eruption phases start or progress). Past examples of successful evacuation (e.g. Pinatubo 1991; see Tayang et al., 1996) operated in a progressive way by enlarging the evacuated area following the evolution of the eruptive activity. Such a procedure has the advantage of allowing the evacuation of the most hazardous areas without causing disastrous social and economic consequences and, in particular, without being pushed to wait for macroscopic unrest signals (in the hopes of absolutely avoiding false alarms). When operating with progressive evacuation, in the first steps (with relatively few people evacuated) residents could be free to choose whether to definitively abandon the red zone, proceeding to the planned "second life", or to wait for some time in temporary housing, likely not very far from the evacuated area.

The association of a prearranged "second life" of evacuated people and of a progressive evacuation could therefore work very well in cases similar to the very long and variable Campi Flegrei unrest from 1950 to the present to help decrease the number of residents and to allow the improvement of urban resilience in the risky areas.

It should be noted that moving several hundred thousand people away to prevent disasters and reallocating them to new permanent positions is a formidable goal which can only be obtained during a well-organised, sufficiently long period. Experiences of massive reallocations of whole urban centres are very rare, and they normally occur after disasters to reconstruct the partially destroyed towns at new sites. We could find only two examples of displacement of whole urban centres to prevent disasters in the literature. The first case is Valmeyer, Illinois (1245 inhabitants), where the population moved the whole town to a new site in 1995 after a catastrophic flood of the Mississippi in 1993 (Rozdilsky, 1996). The second case is Kiruna, Sweden (23000 inhabitants), another town which is going to be moved $3 \mathrm{~km}$ apart because of the hazard posed by ore activities which are causing continu- 
ous ground sinking and felt seismicity (Dineva and Boskovic, 2017).

\section{Conclusion}

The Neapolitan volcanic area, with three explosive volcanoes and about 3 million people closely exposed, has the largest risk in the world. The volcanic risk here is associated with other risks, the main one being the seismic risk. Risk mitigation in this area is, for these reasons, a paradigm for managing all situations of densely populated volcanic areas in the world. It is very clear that, given the present state of the art of volcanology, volcanic-risk mitigation in densely populated areas cannot rely only on eruption forecasting, which is still based on largely uncertain empirical procedures that are not even really quantifiable in a probabilistic way. For this reason, we suggest here that effective mitigation procedures must, in these cases, be flexible enough to take into account economic, social and political considerations in addition to volcanological ones. In fact, in densely populated areas one is faced with the two-fold problem of low reliability of forecasting and no possibility to estimate the size of the eventual eruption. In the present emergency plans for Neapolitan volcanoes, the probability of a missed alarm is practically neglected, and the "red zones" (i.e. the areas to be quickly evacuated before the eruption) are assumed to be very large on a precautionary basis in order to manage the occurrence of even the largest eruptions unless they are considered to be very unlikely. These two assumptions are both very critical: the first one is demonstrated to be simply wrong from all recent eruption experience; the second one, in light of volcanological considerations, is demonstrated to make the evacuation decision too heavy for decision makers because it would be potentially catastrophic in economic and social terms, mainly considering the high probability of a false alarm. Once we demonstrate evidence of the clear faults of the present emergency plans, we show what the guidelines for making them really effective should be. The first, essential requirement for the Neapolitan area is to decrease the population in the most exposed urban zones well before any volcanic emergency. There are economical considerations, which are only mentioned here and are to be addressed more in-depth with the help of economists and social scientists, that could make such a difficult task feasible in this region. Another imperative action is to improve the quality of buildings, reinforcing them to be resistant to earthquakes, which unavoidably precede and accompany both eruptions and unrest episodes. Once the closest urban areas are made more resistant and hence more resilient, the possible evacuation before an impending eruption must be thoroughly organised in advance so as to minimise the economic and social impacts. In addition, a really feasible emergency plan should consider a "progressive" evacuation, which would start from the most risky area and then progressively proceed to farther areas if the precursory signals increase or eruption starts.

Besides the peculiarity of the Neapolitan area, the most striking guidelines to be followed in any densely populated volcanic area can be summarised in a few important points:

- If possible, decrease the resident population density in the most risky areas.

- Improve the resistance of the buildings and, in general, the quality of infrastructure and the resilience of urban centres.

- Plan in great detail the possible evacuation well before any emergency by registering the population and its changes over time so that it can be relocated with jobs and services in new places. This will minimise economic and social costs.

- Identify the most risky areas very close to the possible vent opening or in large polygenetic volcanic fields as soon as possible and well before the emergency. Then, rather than a massive total evacuation of the red zone, plan a progressive one starting from the areas closest to the likely vent and involving those farthest from it only when precursory signals are extremely evident or the first eruptive phases start.

In conclusion, mitigation of extreme volcanic risk in densely populated areas requires a widely multidisciplinary approach, which starts with volcanological considerations but heavily involves several disciplines: economics, social sciences, city planning, information technology etc. Nearly 70 cities with populations exceeding 100000 live with the threat of volcanic eruptions (Heiken, 2013); therefore the elements and conclusions presented here will have value worldwide.

Data availability. No data sets were used in this article.

Author contributions. GDN wrote the manuscript with contributions from all co-authors. CT mainly edited Sects. 4 and 5 about the existing evacuation plans, while RS mainly edited the part related to the economic considerations. CT and RS both prepared the figures.

Competing interests. The authors declare that they have no conflict of interest.

Acknowledgements. We gratefully acknowledge the constructive review by Roberto Moretti, Marco Sacchi and Giuseppe Rolandi as well as the helpful comments by Chris Kilburn and Paolo Harabaglia. They significantly improved the first version of the paper. 
Review statement. This paper was edited by Heidi Kreibich and reviewed by Roberto Moretti and Marco Sacchi.

\section{References}

Acocella, V. and Funiciello, R.: The interaction between regional and local tectonics during resur-gent doming: the case of the island of Ischia, Italy, J. Volcanol. Geoth. Res., 88, 109-123, 1999.

Astarita, T.: Naples is the whole World, in: a Companion to Early Modern Naples, Brill's Companion to European History, 2, https://doi.org/10.1163/9789004251830_002, 2013 (in Italian).

Barberi, F. and Carapezza, M. L.: The Problem of Volcanic Unrest: The Campi Flegrei Case History, in: Monitoring and Mitigation of Volcano Hazards. Springer, Berlin, Heidelberg, Germany, 1996.

Bellucci, F., Milia, A,, Rolandi, G., and Torrente, M. : Structural control on the Upper Pleistocene ignimbrite eruptions in the Neapolitan area (Italy): volcano tectonic faults versus caldera faults, Dev. Volcano., 9, 163-180, 2006a.

Bellucci, F., Woo, J., Kilburn, C. R. J., and Rolandi, G.: Mechanisms of Activity and Unrest at Large Calderas, edited by: Troise, C., De Natale, G., and Kilburn, C. R. J., Geol. Soc. London Spec. Publ., vol. 269, 141-158, 2006 b.

Bevilacqua, A., Isaia, R., Neri, A., Vitale, S., Aspinall, W. P., Bisson, M., Flandoli, F., Baxter, P. J., Bertagnini, A., Esposti Ongaro, T., Iannuzzi, E., Pistolesi, M., and Rosi, M.: Quantifying volcanic hazard at Campi Flegrei caldera (Italy) with uncertainty assessment: 1. Vent opening maps, J. Geophys. Res.-Sol. Ea., 120, 2309-2329, https://doi.org/10.1002/2014JB011775, 2015.

Calderoni, G., Di Giovambattista, R., Pezzo, G., Albano, M., Atzori, S., Tolomei, C., and Ventura, G.: Seismic and geodetic evidences of a hydrothermal source in the Md 4.0, 2017, Ischia earthquake (Italy), J. Geophys. Res.-Sol. Ea., 124, 5014-5029, https://doi.org/10.1029/2018JB016431, 2019.

Capuano, P. and Achauer, U.: Gravity field modeling in the vesuvius and campanian area, in The TomoVes Seismic Project: Looking Inside Mt. Vesuvius, edited by: Zollo, A., Gasparini, P., and Bobbio, A., Cuen, Napoles, Italy, 2003.

Carlino, S., Cubellis, E., Luongo, G., and Obrizzo, F.: On the mechanics of caldera resurgenceof Ischia Island (southern Italy), in: Mechanisms of Activity and Unrest at large Calderas, edited by: Troise, C., De Natale, G., and Kilburn, C., Geological Society 269. Special Publications, London, UK, 181-193, 2006.

Carlino, S., Somma, R., and Mayberry, G. C.: Volcanic risk perception of young people in the urban areas of Vesuvius: Comparison with other volcanic areas and implications for emergency management, J. Volcanol. Geoth. Res., 172, 229-243, https://doi.org/10.1016/j.jvolgeores.2007.12.010, 2008.

Carratelli, G. P.: Megale Hellàs, Scheiwiller ed., Milano, Italy, 744 pp., 1983 (in Italian).

Cassano, E. and La Torre, P.: Geophysics, in: Phlegrean Fields, edited by: Rosi, M. and Sbrana, A., CNR Quad. Ric. Sci. 114, 103-133, 1987.

Chiodini, G., Paonita, A., Aiuppa, A., Costa, A., Caliro, S., De Martino, P., Acocella, V., and Vandemeulebrouck, J.: Magmas near the critical degassing pressure drive volcanic unrest towards a critical state, Nat. Commun. 7, 13712, https://doi.org/10.1038/ncomms13712, 2016.
Cinque, A. and Romano, P. : Segnalazione di nuove evidenze di antiche linee di riva in Penisola Sorrentina, Campania, Geogr. Fis. Dinam. Quat., 13, 23-26, 1990.

Consensus Study Report: Volcanic Eruptions and Their Repose, Unrest, Precursors, and Timing, The National Academy Press, 134 pp., https://doi.org/10.17226/24650, 2017.

Cubellis, E. and Lungo, G.: Il terremoto del 28 luglio 1883 a Casamicciola nell'Isola di Ischia - Il contest fisico, in: Monografia n. 1, Presidenza del Consiglio dei Ministri, Servizio Sismico Nazionale. Istituto Poligrafico e Zecca dello Stato, Rome, Italy, 49-123, 1998 (in Italian).

Della Vedova, B., Bellani, S., Pellis, G., and Squarci, P.: Deep temperatures and surface heat flow distribution, in: Anatomy of an Orogen: the Apennines and Adjacent Mediterranean basins, edited by: Vai, G. B. and Martini, I. P., Kluwer Academic Publishers, Dordrecht, the Netherlands, 65-76, 2001.

De Natale, G. and Pingue, F.: Ground deformations in collapsed caldera structures, J. Volcanol. Geoth. Res., 57, 19-38, https://doi.org/10.1016/0377-0273(93)90029-Q, 1993.

De Natale, G., Pingue, F., Allard, P., and Zollo, A.: Geophysical and geochemical modelling of the 1982-1984 unrest phenomena at Campi Flegrei caldera (southern Italy), J. Volcanol. Geoth. Res., 48, 199-222, 1991.

De Natale, G., Petrazzuoli, S. M., and Pingue, F.: The effect of collapse structures on ground deformations in calderas, Geophys. Res. Lett., 24, 1555-1558, 1997.

De Natale, G., Petrazzuoli, S. M., Troise, C., Pingue, F., and Capuano, P. : Internal stress field at Mount Vesuvius: A model for background seismicity at a central volcano, J. Geophys. Res., 105, 16207-16214, https://doi.org/10.1029/2000JB900031, 2000.

De Natale, G., Kuznetzov, I., Kronrod, T., Peresan, A., Saraò, A., Troise, C., and Panza, G.F.: Three decades of seismic activity at Mt. Vesuvius: 1972-1999, Pure Appl. Geophys., 161, 123-144, https://doi.org/10.1007/s00024-003-2430-0, 2004.

De Natale, G., Troise, C., Pingue, F., Mastrolorenzo, G., and Pappalardo, L.: The Somma-Vesuvius volcano (Southern Italy): Structure, dynamics and hazard evaluation, Earth-Sci. Rev., 74, 73-111, https://doi.org/10.1016/j.earscirev.2005.08.001, 2005.

De Natale, G., Troise, C., Mark, D., Mormone, A., Piochi, M., Di Vito, A. M., Isaia, R., Carlino, S., Barra, D., and Somma, R.: The Campi Flegrei Deep Drilling Project (CFDDP): New insight on caldera structure, evolution and hazard implications for the Naples area (Southern Italy), Geochem. Geophy. Geosy., 17, 4836-4847, https://doi.org/10.1002/2015GC006183, 2016.

De Natale, G., Petrazzuoli, S., Romanelli, F., Troise, C., Vaccari, F., Somma, R., Peresan, A., and Panza, G. F.: Seismic risk mitigation at Ischia island (Naples, Southern Italy): an innovative approach to prevent catastrophic scenarios, Eng. Geol., 261, 105285, https://doi.org/10.1016/j.enggeo.2019.105285, 2019.

De Novellis, V., Carlino, S., Castaldo, R., Tramelli, A., De Luca, C.,Pino, N.A., Pepe, S., Convertito, V., Zinno, I., De Martino, P., Bonano, M., Giudicepietro, F., Casu, F., Macedonio, G., Manunta, M., Cardaci, C., Manzo, M., Di Bucci, D., Solaro, G., Zeni, G., Lanari, R., Bianco, F., and Tizzani, P.: The 21 August 2017 Ischia (Italy) earthquake source model inferred from seismological, GPS, and DInSAR measurements, Geophys. Res. Lett., 45, 2193-2202, https://doi.org/10.1002/2017GL076336, 2018. 
de Vita, S., Sansivero, F., Orsi, G., and Marotta, E.: Cyclical slope instability and volcanism related to volcano-tectonism in resurgent calderas: The Ischia island (Italy) case study, Eng. Geol., 86, 148-165, https://doi.org/10.1016/j.enggeo.2006.02.013, 2006.

de Vita, S., Sansivero, F., Orsi, G., Marotta, E., and Piochi, M.: Volcanological and structural evolution of the Ischia resurgent caldera (Italy) over the past $10 \mathrm{k} . \mathrm{y}$, in: Stratigraphy and Geology of Volcanic Areas,edited by: Groppelli, G. and Viereck-Goette, L., Geol. Soc. Am. Sp. Pap., Boulder, CO, USA, vol. 464, 193241, 2010

Di Girolamo, P.: Petrografia dei tufi Campani: I1 processo di pipernizzazione (tufo $->$ tufo pipernoide $->$ piperno), Rend. Acc. Sci. Fis. Mat. Napoli, 5, 4-25, 1968.

Dineva, S. and Boskovic, M.: Evolution of seismicity at Kiruna Mine, in: Proceedings of the Eighth International Conference on Deep and High Stress Mining, 28-30 March 2017, Perth, Australia, edited by: Wesseloo, J., Australian Centre for Geomechanics, 125-139, https://doi.org/10.36487/ACG_rep/1704_07_Dineva, 2017.

Dipartimento di Protezione Civile Nazionale: Gazzetta Ufficiale Gazzetta Ufficiale,75 del 31 marzo 201, p. 9, available at: https://www.gazzettaufficiale.it/atto/serie_generale/ caricaDettaglioAtto/originario?atto.dataPubblicazioneGazzetta= 2015-03-31\&atto.codiceRedazionale $=15$ A02488\& elenco30giorni=false (last access: 20 July 2020), 2015.

Ferrucci, F., Gaudiosi, G., Pino, N. A., Luongo, G., Hirn, A., and Mirabile, L.: Seismic detection of a major moho upheaval beneath the Campania volcanic area (Naples, southern Italy), Geophys. Res. Lett., 16, 1317-1320, https://doi.org/10.1029/GL016i011p01317, 1989.

Forni, F., Degruyter, W., Bachmann, O., De Astis, G., and Mollo, S.: Long-term magmatic evolution reveals the beginning of a new caldera cycle at Campi Flegrei, Sci. Adv., 4, eaat9401 https://doi.org/10.1126/sciadv.aat9401, 2018.

Gaeta, F. S., Peluso, F., Arienzo, I., Castagnolo, D., De Natale, G., Milano, G., Albanese, C., and Mita, D. G.: A physical appraisal of a new aspect of bradyseism: the miniuplifts, J. Geophys. Res., 108, 2363, https://doi.org/10.1029/2002JB001913, 2003.

Giannetti, B. and Luhr, J. F.: The White Trachytic Tuff of Roccamonfina Volcano (Roman Region, Italy), Contrib. Mineral. Petr., 84, 235-252, 1983.

Heiken, G.: Dangerous Neighbors: Volcanoes and Cities, edited by: Heiken, J., Cambridge University Press, Cambridge, UK, V-Vi, 2013

Iuliano, S., Matano, F., Caccavale, M., and Sacchi, M.: Annual rates of ground deformation (1993-2010) at Campi Flegrei, Italy, revealed by Persistent Scatterer Pair (PSP) - SAR interferometry, Int. J. Remote Sens., 36, 6160-6191, 2015.

Kilburn, C. R. J.: Precursory deformation and fracture before brittle rock failure and potential application to volcanic unrest, J. Geophys. Res., 117, B02211, https://doi.org/10.1029/2011JB008703, 2012.

Kilburn, C. R. J., De Natale, G., and Carlino S.: Progressive approach to eruption at Campi Flegrei caldera in Southern Italy, Nat. Commun., 8, 15312, https://doi.org/10.1038/ncomms15312, 2017.

Marzocchi, W., Sandri, L., Gasparini, P., Newhall, C., and Boschi, E.: Quantifying probabilities of volcanic events: The example of volcanic hazard at Mount Vesuvius, J. Geophys. Res., 109, B11201, https://doi.org/10.1029/2004JB003155, 2004.

Mastrolorenzo, G., Petrone, P., Pappalardo, L., and Sheridan, M. F. The Avellino 3780-yr-B.P. catastrophe as a worst-case scenario for a future eruption at Vesuvius, P. Natl. Acad. Sci. USA, 103, 4366-4370, https://doi.org/10.1073/pnas.0508697103, 2006a.

Mastrolorenzo, G., Pappalardo, L., Troise, C., Rossano, S., Panizza, A., and De Natale, G.: Volcanic hazard assessment at Campi Flegrei caldera, Geol. Soc. Lond., 269, 159-171, 2006 b.

Mastrolorenzo, G., Palladino, D. M., Pappalardo, L., and Rossano, S.: Probabilistic-numerical assessment of pyroclastic current hazard at Campi Flegrei and Naples city: Multi-VEI scenarios as a tool for "full-scale" risk management, PLoS ONE, 12, e0185756, https://doi.org/10.1371/journal.pone.0185756, 2017.

Mazzarella, A., Martone, M., and Tranfaglia, G.: The latest flood event of 4-5 May 1998 in the Sarno area and the inadequate resolution of the rain-gauge network, Quaderni di Geologia Applicata, Ed Pitagora, Bologna, Italy, 203-211, 2002 (in Italian).

Molin, P., Acocella, V., and Funiciello, R.: Structural, seismic and hydrothermal features at the border of an active intermittent resurgent block: Ischia island (Italy), J. Volcanol. Geoth. Res., 121, 65-81, 2003.

Moretti, R., Orsi, G., Civetta, L., Arienzo, I., and Papale, P.: Multiple magma degassing sources at an explosive volcano, Earth Planet. Sc. Lett., 367, 95-104, 2013.

Moretti, R., De Natale, G., and Troise, C.: A geochemical and geophysical reappraisal to the significance of the recent unrest at Campi Flegrei caldera (Southern Italy) Geochem. Geophy. Geosy., 18, 1244-1269, https://doi.org/10.1002/2016GC006569, 2017.

Moretti,R., Troise, C., Sarno, F., and De Natale, G.: Caldera unrest driven by $\mathrm{CO}_{2}$-induced drying of the deep hydrothermal system, Sci. Rep., 8, 8309, https://doi.org/10.1038/s41598-018-26610-2, 2018.

Moretti, R., De Natale, G., and Troise, C. Hydrothermal versus magmatic: geochemical views and clues into the unrest dilemma at Campi Flegrei, in: Vesuvius, Campi Flegrei, and Campanian Volcanism, edited by: De Vivo, B., Belkin, H. E., and Rolandi, G., Elsevier, Amsterdam, the Netherlands, 371-406, 2020.

Morhange, C., Marriner, N., Laborel, J., Todesco, M., and Oberlin, C.: Rapid sea-level movements and noneruptive crustal deformations in the Phlegrean Fields caldera, Italy, Geology, 34, 93-96, 2006.

Nappi, R., Alessio, G., Gaudiosi, G., Nave, R., Marotta, E., Siniscalchi, V., Civico, R., Pizzimenti, L., Peluso, R., Belviso, P., and Porfido, S.: The 21 August 2017 MD 4.0 Casamicciola earthquake: first evidence of coseismic normal surface faulting at the Ischia volcanic island, Seismol. Res. Lett., 89, 1323-1334, https://doi.org/10.1785/0220180063, 2018.

Neri, A., Bevilacqua, A., Esposti Ongaro, T., Isaia, R,, Aspinall, W. P., Bisson, M., Flandoli, F., Baxter, P. J., Bertagnini, A., Ianuzzi, E., Orsucci, S., Pistolesi, M., Rosi, M., and Vitale, S.: Quantifying volcanic hazard at Campi Flegrei caldera (Italy) with uncertainty assessment: 2. Pyroclastic density current invasion maps, J. Geophys. Res.-Sol. Ea., 120, 2330-2349, 2015.

Newhall, C. G. and Dzurisin, D.: Historical Unrest at Large Calderas of the World, US Geol. Surv. Bull., 1855, 210-213, 1988. 
Orsi, G., Gallo, G., and Zanchi, A.:S imple shearing blockresurgence in caldera depressions. A model from Pantelleria and Ischia, J. Volcanol. Geoth. Res., 47, 1-11, 1991.

Orsi, G., De Vita, S., and di Vito, M.: The restless, resurgent Campi Flegrei nested caldera (Italy): constraints on its evolution and configuration, J. Volcanol. Geoth. Res., 74, 179-214, https://doi.org/10.1016/S0377-0273(96)00063-7, 1996.

Paoletti, V., Di Maio, R., Cella, F., Florio, G., Mocka, K., Roberti, N., Secomandi, M., Supper, R., Fedi, M., and Rapolla, A.: The Ischia volcanic island (Southern Italy): inferences from potential field data interpretation, J. Volcanol. Geoth. Res., 179, 69-86, https://doi.org/10.1016/j.jvolgeores.2008.10.008, 2009.

Papale, P.: Rational volcanic hazard forecasts and the use of volcanic alert levels, J. Appl. Volcanol, 6, 2-13, https://doi.org/10.1186/s13617-017-0064-7, 2017.

Papale, P. and Marzocchi, W.: Volcanic threats to global society, Science, 363, 1275-1276, https://doi.org/10.1126/science.aaw7201, 2019.

Passaro, S., de Alteriis, G., and Sacchi, M.:. Bathymetry of Ischia Island and its offshore (Italy), scale $1: 50.000$, J. Maps, 12, 152159, https://doi.org/10.1080/17445647.2014.998302, 2015.

Passaro, S., Tamburrino, S., Vallefuoco, M., Gherardi, S., Sacchi, M., and Ventura, G.: High-resolution morpho-bathymetry of the Gulf of Naples, Eastern Tyrrhenian Sea, J. Maps, 12, 203-210, https://doi.org/10.1080/17445647.2016.1191385, 2016.

Peccerillo, A.: Plio-Quaternary Volcanism in Italy, Springer-Verlag, 365 pp., https://doi.org/10.1007/3-540-29092-3, 2005.

Piochi, M., Kilburn, C. R. J., Di Vito, M. A., Mormone, A., Tramelli, A., Troise, C., and De Natale, G.: The volcanic and geothermally active Campi Flegrei caldera: an integrated multidisciplinary image of its buried structure, Int. J. Earth Sci., 103, 401-421, https://doi.org/10.1007/s00531-013-0972-7, 2014.

Robertson, R. M. and Kilburn, C.R. J.: Deformation regime and long-term precursors to eruption at large calderas: Rabaul, Papua New Guinea, Earth Planet. Sc. Lett., 438, 86-94, 2016.

Rolandi, G.: Volcanic hazard at Vesuvius: An analysis for the revision of the current emergency plan, J. Volcanol. Geoth. Res., 189, 347-362, https://doi.org/10.1016/j.jvolgeores.2009.08.007, 2010.

Rolandi, G., Petrosino, P., and McGeehin, J. : The interplinianactivity at Somma - Vesuvius in the last 3500 years, J. Volcanol. Geoth. Res. 82, 19-52, https://doi.org/10.1016/S0377-0273(97)000565, 1998.

Rolandi, G., Bellucci, F., Heizler, M. T., Belkin, H. E., and De Vivo, B.: Tectonic controls on the genesis of ignimbrites from the Campanian Volcanic Zone, southern Italy, Mineral. Petrol., 79, 3-31, 2003.

Rolandi, G., Di Lascio, M., and Rolandi, R.: The 15 ka Neapolitan Yellow Tuff Eruption: An Analysis of the Caldera-forming Phase and the Post-Caldera Volcanic Activity, in: Vesuvius, Campi Flegrei, and Campania Volcanism, edited by: De Vivo, B., Belkin, H. E., and Rolandi, G., Elsevier, Amsterdam, the Netherlands, 2019a.

Rolandi, G., De Natale, G., Kilburn, C. R. J., Troise, C., Somma, R., Di Lascio, M., Fedele, A., and Rolandi, R.: The 39 ka Campanian Ignimbrite eruption: new data on source area in the Campanian Plain, in: Vesuvius, Campi Flegrei, and Campania Volcanism, edited by: De Vivo, B., Belkin, H. E., and Rolandi, G., Elsevier, Amsterdam, the Netherlands, 175-205, 2019b.
Rosi, M. and Sbrana, A.: Phlegrean Fields, Quaderni de la Ricerca Scientifica, CNR, Rome, Italy, 114, 60-79, 1987.

Rossano, S., Mastrolorenzo, G., and De Natale, G.: Computer simulations of pyroclastic flows on Somma-Vesuvius volcano, J. Volcanil. Geoth. Res., 82, 113-137, 1998.

Rossano, S., Mastrolorenzo, G., and De Natale, G.: Numerical simulation of pyroclastic density currents on Campi Flegrei topography: a tool for statistical hazard estimation, J. Volcanol. Geoth. Res., 132, 1-14, 2004.

Rouchon, V. Gillot, P. Y., Quidelleur, X., Chiesa, S., and Floris, B.: Temporal Evolution of the Roccamonfina volcanic complex (Pleistocene), Central Italy, J. Volcanol. Geoth. Res., 177, 500514, https://doi.org/10.1016/j.jvolgeores.2008.07.016, 2008.

Rozdilsky, J. L.: Flood-related relocation of Valmeyer: Implications for the development of sustainable cities, Environment and Planning Newsletter Environmental, Natural Resources and Energy Division, American Planning Association, Center for Urban Policy and the Environment, School of Public and Environmental Affairs, Indiana University - Purdue University Indianapolis, IN, USA, 1, 1-3, 1996.

Sacchi, M., Molisso, F., Esposito, E., Insinga, D., Lubritto, C., Porfido, S., Tóth, T., and Violante, C.: Insights into flood-dominated fan deltas: very high-resolution seismic examples off the Amalfi cliffed coasts, Eastern Tyrrhenian Sea, in: Geohazard in Rocky Coastal Areas, edited by: Violante, C., The Geological Society, London, Special Publications, 322, 33-71, 2009.

Sacchi, M., De Natale, G., Spiess, V., Steinmann, L., Acocella, V., Corradino, M., de Silva, S., Fedele, A., Fedele, L., Geshi, N., Kilburn, C., Insinga, D., Jurado, M.-J., Molisso, F., Petrosino, P., Passaro, S., Pepe, F., Porfido, S., Scarpati, C., Schmincke, H.U., Somma, R., Sumita, M., Tamburrino, S., Troise, C., Vallefuoco, M., and Ventura, G.: A roadmap for amphibious drilling at the Campi Flegrei caldera: insights from a MagellanPlus workshop, Sci. Dril., 26, 29-46, https://doi.org/10.5194/sd-2629-2019, 2019.

Sacchi, M., Passaro, S., Molisso, F., Matano, F., Steinmann, L., Spiess, V., Pepe, F., Corradino, M., Caccavale, M., Tamburrino, S., Esposito, G., Vallefuoco, M., and Ventura, G.: The Holocene marine record of unrest, volcanism, and hydrothermal activity of Campi Flegrei and Somma Vesuvius, in: Vesuvius, Campi Flegrei, and Campanian Volcanism, edited by: De Vivo, B., Belkin, H. E., and Rolandi, G., Elsevier Inc., Amsterdam, the Netherlands, 435-469, 2020.

Santacroce, R.: A general model for the behavior of the SommaVesuvius volcanic complex, J. Volcanol. Geoth. Res., 17, 237 248, 1983.

Sbrana, A., Fulignati, P., Marianelli, P., Boyce, A. J., and Cecchetti, A.: Exhumation of an active magmatic-hydrothermal system in a resurgent caldera environment. The example of Ischia Island (Italy), J. Geol. Soc. London, 166, 1061-1073, 2009.

Scandone, R., Bellucci, F., Lirer, L., and Rolandi, G.: The structure of the Campanian Plain and the activity of the Neapolitan Volcanoes (Italy), J. Volcanol. Geoth. Res., 48, 1-31, 1991.

Scandone, R., Arganese, G., and Galdi, F.: The evaluation of volcanic risk in the Vesuvian area, J. Volcanol. Geoth. Res., 58, 263 271, 1993.

Scandone, R., Giacomelli, L., and Rosi, M.: Death, Survival and Damage during the 79 AD Eruption of Vesuvius which de- 
stroyed Pompeii and Herculaneu, J. Res. Didact. Geogr., 2, 5-30, https://doi.org/10.4458/2801-01, 2019.

Solana, M. C., Kilburn, C. R. J., and Rolandi, G.: Communication eruption and hazard forecasts on Vesuvius, Southern Italy, J. Volcanol. Geoth. Res., 172, 308-314, https://doi.org/10.1016/j.jvolgeores.2007.12.027, 2008.

Somma, R., Iuliano, S., Matano, F., Molisso, F., Passaro, S., Sacchi, M., Troise, C., and De Natale, G.: High-resolution morphobathymetry of Pozzuoli Bay, southern Italy, J. Maps, 12, 222230, https://doi.org/10.1080/17445647.2014.1001800, 2016.

Stefánsson, R.: Advances in Earthquake Prediction, Research and Risk Mitigation, Springer-PRAXIS, Berlin, Germany, 271 pp., 2011.

Steinmann, L., Spiess, V., and Sacchi, M.: Post-collapse evolution of a coastal caldera system: Insights from a 3D multichannel seismic survey from the Campi Flegrei caldera (Italy), J. Volcanol. Geoth. Res., 349, 83-98, 2018.

Tayang, J., Insauriga, S., Ringor, A., and Belo, M.: People's Response to Eruption Warning: The Pinatubo Experience, 1991-92, in: Fire and mud: eruptions and lahars of Mount Pinatubo, edited by: Newhall, C. G. and Punongbayan, R. S., Philippine Institute of Volcanology and Seismology, Quezon City, Philippines, and University of Washington Press, Seattle, USA, 67-85, 1996.

Tibaldi, A. and Vezzoli, L.: The space problem of caldera resurgence: an example from Ischia Island, Italy, Geol. Rundsch., 87, 53-66, 1998.

Troise, C., De Natale, G., Pingue, F., Obrizzo, F., De Martino, P., Tammaro, U., and Boschi, E.: Renewed ground uplift at Campi Flegrei caldera (Italy): New insight on magmatic processes and forecast, Geophys, Res. Lett, 34, L03301, https://doi.org/10.1029/2006GL028545, 2007.
Troise, C., De Natale, G., Schiavone, R., Somma, R.. and Moretti, R.: The Campi Flegrei caldera unrest: Discriminating magma intrusions from hydrothermal effects and implications for possible evolution, Earth-Sci. Rev., 18, 108-122, https://doi.org/10.1016/j.earscirev.2018.11.007, 2019.

Vanorio, T. and Kanitpanyacharoen, W.: Rock physics of fibrous rocks akin to Roman concrete explains uplifts at Campi Flegrei Caldera, Science, 349, 617-621, https://doi.org/10.1126/science.aab1292, 2015.

Vezzoli, L. (Ed.): Island of Ischia, C. N. R. Quaderni de "La Ricerca scientifica”, 114, 135 pp., Rome, Italy, 1988.

Winson, A. E. G., Costa, F., Newhall, C. G., and Woo, G.: 2014 An analysis of the issuance of volcanic alert levels during volcanic crises, J Appl. Volcanol. 3, 2-12, https://doi.org/10.1186/s13617014-0014-6, 2014.

Zollo, A., Gasparini, P., Virieux, J., Le Meur, H., De Natale, G., Biella, G., and Boschi, E.: Seismic evidence for a low velocity zone in the upper crust beneath Mt. Vesuvius, Science, 274, 592594, 1996.

Zollo, A., Maercklin, N., Vassallo, M., Dello Iacono, D., Virieux, J., and Gasparini, P.: Seismic reflections reveal a massive melt layer feeding Campi Flegrei caldera, Geophys. Res. Lett., 35, L12306, https://doi.org/10.1029/2008GL034242, 2008. 